\title{
Identification of hypothetical duplicate accessions of plums (Prunus domestica L.) within the slovene plant gene bank collection using molecular markers
}

\author{
Metka ŠIŠKO \\ University of Maribor, Faculty of Agriculture and Life Sciences, Pivola 10, 2311 Hoče, Slovenia
}

\begin{abstract}
The main goal of the Slovene Plant Gene Bank is preservation, maintenance and evaluation of traditional cultivars and other useful genotypes. The Faculty of Agriculture and Life Sciences houses among other plant materials also numerous accessions of plums (Prunus domestica L.). Duplicates among 15 accessions were studied using six microsatellite primer pairs. These microsatellite markers revealed an average of 7.67 alleles per locus, and a range of 4 to 10 different alleles per locus. The genetic distances between studied accessions were calculated using the Dice coefficient to form a dendrogram. The six SSRs were found to be adequate for differentiating among genotypes within the collection. Among the analysed accessions no duplicates were found.
\end{abstract}

Key words: gene bank, duplicate accessions, Prunus domestica, plums, SSR markers

\section{INTRODUCTION}

In 1996, the Ministry of Agriculture, Forestry and Food began participating in financing the Slovene Plant Gene Bank Program (SRGB) and its main aims were to maintain, evaluate, regenerate and preserve Slovenian indigenous germplasm such as Slovenian local ecotypes, populations and landraces of agricultural, medicinal and aromatic plants, forest trees and other woody plants from Slovenian forests. The gene bank includes Slovenian currently grown cultivars, abandoned cultivars (cultivars grown in the past), landraces, local populations, clones and lines bred from indigenous plant materials and ecotypes from various natural habitats important for food, and other genotypes important for agriculture and forestry. In the activities of the Slovene Plant Gene Bank Program dealing with agricultural, medicinal and aromatic plants, four institutions are involved: Biotechnical faculty of the University of Ljubljana, Institute for Hop Research and Brewing of Slovenia, Žalec, Faculty for Agriculture and Life Sciences of University of Maribor, and the Agricultural Institute of Slovenia, Ljubljana (Meglic et al. 2014).
The germplasm collection at the Faculty of Agriculture and Life Sciences, University of Maribor, houses among others, accessions of plums (Prunus domestica L.). One of the most common problems of gene banks is unintentionally duplication of samples. The reasons could be different local names for the same cultivar, different persons collecting the plant material, collection of the plant materials in different environments (the same cultivar may be phenotypically very different) and/or mistakes during sampling and/or maintenance.

The best way to determine the hypothetical duplicate accessions is through analysis of genetic similarity. In particular, DNA based markers have the advantage of being unaffected by environment. Approaches for the identification of duplicate accessions based on DNA markers are most frequently associated with studies of dendrograms (Lund et al. 2003; Cervera et al. 1998). Microsatellite markers have been used successfully to assess the diversity of wild and clonally propagated fruit plants collections (Gross et al. 2012; Koehmstedt et al. 2011; Laucou et al. 2011). As a result of high levels of allelic diversity within most Prunus species (Decroocq et al. 2004; Donoso et al. 2008; Struss et 
al. 2003), relatively few markers are required to differentiate among unique $P$. domestica cultivars. The number of primers sufficient for reliable variety identification depends on the nature and discriminating power of each primer (Tessier et al. 1999) and normally six primer pairs are sufficient for differentiating between genotypes (Zulini et al. 2002).

In the present study, six SSR loci were used to assess genetic diversity among 15 plum genotypes.

\section{MATERIALS AND METHODS}

\section{Plant material}

The study involve 15 plum accessions (Table 1) which are grown in the national plum germplasm collection which is housed at the estate of the Faculty of Agriculture and Life Sciences, in the vicinity of the University Botanical Garden. The whole plum collection includes 136 accessions originating from various parts of Slovenia.

\section{DNA extraction}

DNA was extracted from fresh, young leaves using the CTAB protocol. To approximately $2-3 \mathrm{~cm}^{2}$ of fresh leaf tissue, one $\mathrm{ml}$ of preheated $\left(68^{\circ} \mathrm{C}\right) \mathrm{CTAB}$ extraction buffer (Doyle and Doyle 1987) was added and well homogenized in a mortar with the pestle, and transferred to a $1.5 \mathrm{ml}$ tube. Samples were incubated for $1.5 \mathrm{~h}$ at $68{ }^{\circ} \mathrm{C}$ in a water bath. After incubation, $600 \mu \mathrm{L}$ of chloroform:isoamyl alcohol in a 24:1 proportion was added, and the samples were thoroughly mixed. The mixtures were centrifuged at 14.200 gn for 15 min. After centrifugation, the supernatant was transferred to a fresh tube, and the DNA was precipitated by the addition of 0.1 volume of $3 \mathrm{M}$ sodium acetate and 1 volume of ice cold isopropanol and kept at $-20^{\circ} \mathrm{C}$ for $30 \mathrm{~min}$. Samples were again centrifuged at $14.200 \mathrm{gn}$ for $15 \mathrm{~min}$. The pellet was washed in $70 \%$ ethanol, air dried and rehydrated in $100 \mu$ of TE buffer. Two separate extractions per plant were performed.The quality of extracted DNA was determined by agarose electrophoresis, and the quantity of obtained DNA was measured using the fluorometer DQ 300 (Hoefer, Holliston, Massachusetts).

\section{SSR markers and PCR}

The six previously isolated and characterized SSRs loci (Table 2) for sweet cherry (P. avium) were selected (EMPA001, EMPA002, EMPA003, EMPA004, EMPA011, EMPA029) from published papers (Clarke and Tobutt 2003, Guarino et al. 2009, Clarke et al. 2008) and their usefulness in ability to amplify a product also in $P$. domestica were determined. There is a high degree of homology for the SSR loci and transportability of these markers among Prunus species (Donoso et al. 2008). For testing the primer pairs, unlabelled primers (Sigma, Germany) were used in PCR. For six selected primers, one primer of each primer pair was labelled with fluorescent dye Cy5 or Cy5.5. The use of different dyes made possible to analyse three PCR products on capillary electrophoresis in the same reaction.

Ten $\mu \mathrm{l}$ of PCR mixture contained $2 \mathrm{ng}$ DNA, $0.5 \mu \mathrm{l}$ of each primer and $5 \mu$ of Multipleks PCR Plus Kit (Qiagen $\mathrm{GmbH}$, Hilden). PCR conditions were previously optimised for each primer pair considering annealing temperature and number of cycles. For all primers the annealing temperature of $55^{\circ} \mathrm{C}$ and 30 cycles were used. The polymerase chain reaction (PCR) was performed using a Whatman Biometra T-Gradient thermocycler (Goettingen, Germany). The capillary electrophoresis (Figure 1) of PCR products was performed on Beckman Coulter CEQ8000 according to manufacturer's instructions. The fragment size analysis was done with the in-build software. A fluorescently labelled size marker (Beckman Coulter DNA Size Standard Kit 400 bp) was used as a molecular weight reference.

\section{Data analysis}

All unambiguous fragments were scored for the presence (1) or absence (0) of each band. Only clear and reproducible fragments were taken for data analysis. The binary data matrix was used to calculate Dice's similarity coefficients (Dice 1945). Values for Dice's coefficients fall between 0 (there is no common band) and 1 (two genotypes have identical markers, so they are identical). Dice similarity coefficients were calculated using the DARWIN computer package (Perrier and Jacquemond-Collet 2005). For each microsatellite locus, the number of alleles per locus $(n)$, allele frequencies, observed heterozygosity $\left(H_{O}\right)$, expected heterozygosity $\left(H_{E}\right)$ and probability of identity (PI) were calculated using the 'IDENTITY 1.0' computer program (Wagner and Sefc 1999). The average distance between pairs of accessions was obtained by taking into account microsatellite data, and a neighbor-joining tree was constructed using the DARWIN computer package. A matrix of Dice similarity coefficients was used for assessing relationships among 15 genotypes, using the neighbor-joining algorithm developed by Saitou and Nei (1987).

\section{RESULTS}

DNA was successfully isolated from all 15 accessions of studied plums. The smallest concentration of DNA measured was $47.46 \mu \mathrm{g} / \mathrm{ml}$ (sample 15), and the largest amount of DNA was $422.3 \mu \mathrm{g} / \mathrm{ml}$ for sample 10 (data not shown). DNA isolated from fresh leaves was sufficient for further analysis for all accessions.

SSR analysis revealed 46 polymorphic alleles at 6 microsatellite loci (Table 3). The number of alleles (Table 4) detected per locus ranged from 4 (locus EMPA003) to 10 (locus EMPA011), with an average of 7.67 alleles per locus. The observed heterozygosity ranged between 0.63 (locus EMPA003) and 0.86 (locus EMPA011), with an average of 0.77 . The expected heterozygosity ranged between 0.91 (locus EMPA002) and 1.00 (all other loci), with an average of 0.99 . The differences between the observed and expected heterozygosity were examined for all investigated loci. At 


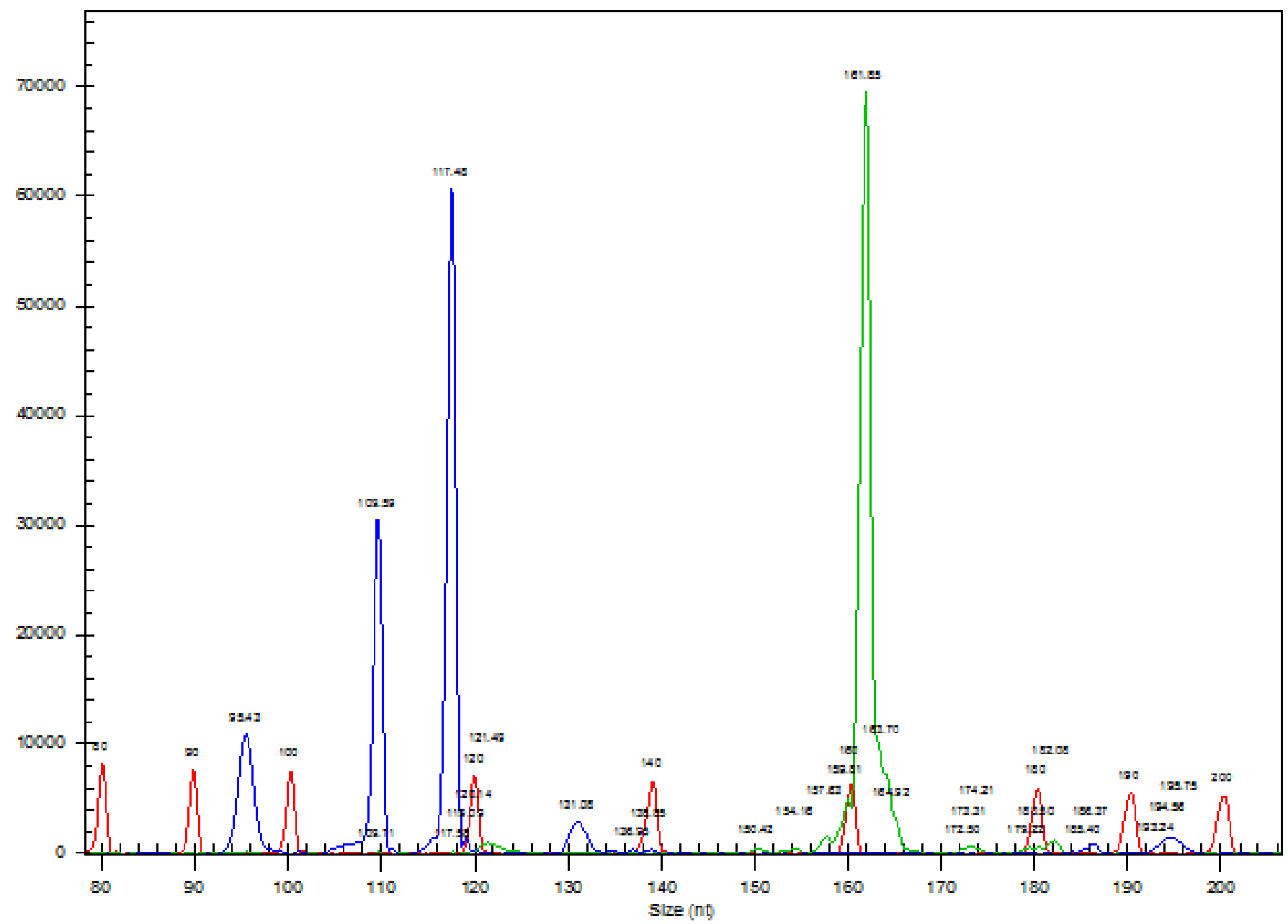

Fig. 1: Fragment lengths (bp) for two SSR loci EMPA004 (green) and EMPA001 (blue) obtained with capillary electrophoresis.

all loci the expected heterozygosity $\left(\mathrm{H}_{\mathrm{E}}\right)$ was higher than observed (Ho). Allele sizes and allele frequencies are listed in Table 5.

The most informative locus for our set of genotypes was EMPA011, with a probability of identity (PI) of 0.067 , and the least informative locus was EMPA003, with a PI of 0.353. The cumulative probability of obtaining identical genotypes using all 6 loci was low (4.77394E-06).

The dendrogram based on microsatellite data (Figure 2) grouped analysed samples in three main clusters. In the Cluster III, there was only one sample named "Drobna plavkica", suggesting that this genotype had a quite different genetic background comparing it with other plum genotypes included in our study.

The second group, Cluster II, included 5 accessions and all belonged to the group "Ringloji". Inside of this cluster the sample number 15 ("Rdečelistni ringlo s krvavo rdečimi plodovi") exhibited the most different germplasm. There were no duplicates in this cluster.

In the first cluster (Cluster I) all other 9 accessions can be found. Sample number 13, which was thought to be from group "Ringlo" showed the most similar genetic background with 'HZW Meschenmoser' in Cluster I. This genotype also showed some morphological differences comparing with other from "Ringlo" group: mesocarp and endocarp could be separated easily and the fruits were bigger in size.

\section{CONCLUSIONS}

In the present study, 15 plum accessions from the Slovene Plant Gene Bank were analysed for hypothetical duplicates. The six microsatellite loci which had been used earlier for genetic studies of sweet cherries were successfully applied in genetic evaluation of plums. Our study showed that there were two major clusters of genotypes and one variety ("Drobna plavkica") which was genetically very different and could be considered as separate genotype. Among 15 analysed genotypes, no duplicates were found.This paper presents some preliminary results of an ongoing project aimed to assess all possible duplicates among accession of the plum collection. 


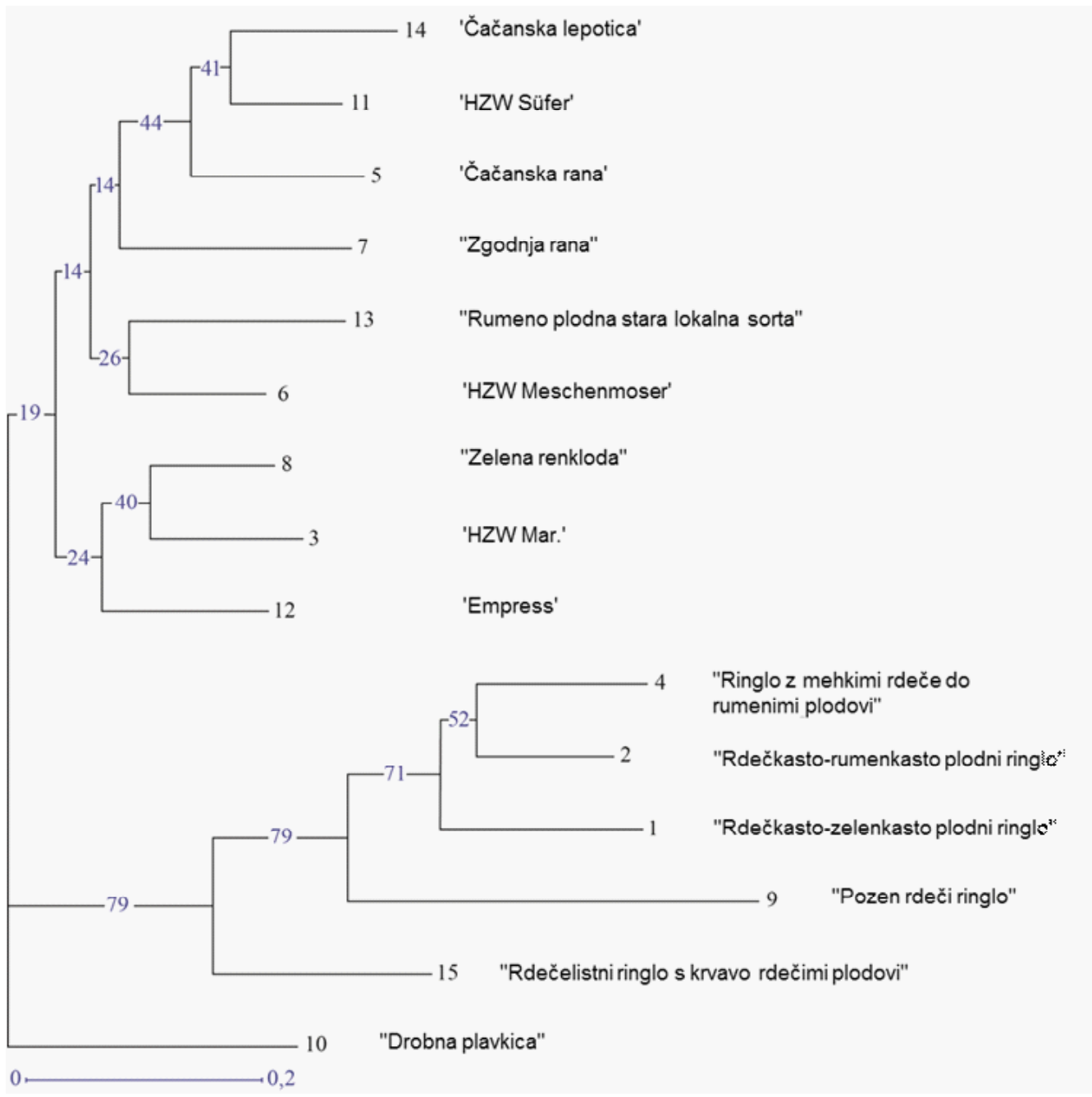

Fig. 2: Neighbour-joining dendrogram of 15 plum accessions relationships obtained from SSR data.

Table 1: Plant material obtained from the Slovene Plant Gene Bank.

\begin{tabular}{|l|l|l|}
\hline Sample & Accession number & Name \\
\hline 1 & 3568 & "Rdečkasto-zelenkastoplodniringlo" \\
\hline 2 & 3569 & "Rdečkasto-rumenkastoplodniringlo" \\
\hline 3 & 3570 & 'HZW Mar. ' \\
\hline 4 & 3571 & "Ringlo z mehkimirdeče do rumenimiplodovi" \\
\hline 5 & 3567 & 'Čačanska rana' \\
\hline 6 & 3572 & 'HZW Meschenmoser' \\
\hline 7 & 3573 & "Zgodnjatemna" \\
\hline 8 & 3574 & "Zelenarenkloda" \\
\hline 9 & 3575 & "Pozenrdečiringlo" \\
\hline 10 & 3576 & "Drobnaplavkica" \\
\hline 11 & 3577 & 'HZW Schüfer' \\
\hline 12 & 3578 & 'Empress' \\
\hline 13 & 3579 & "Rumenoplodnastaralokalnasorta" \\
\hline 14 & 3580 & 'Čačanskalepotica' \\
\hline 15 & 3581 & "Rdečelistniringlo s krvavordečimiplodovi" \\
\hline
\end{tabular}


Table 2: Repeat motifs, primer sequences, and references for six SSR loci used in the study.

\begin{tabular}{|l|l|l|l|}
\hline Locus & Repeat motif & Sequence $\left(5^{\prime} \rightarrow 3^{\prime}\right)$ & Reference \\
\hline EMPA001 & {$[\mathrm{AG}]_{4}$ GGGT $[\mathrm{AG}]_{26}$} & $\begin{array}{l}\text { F: GCTCTGCTGCTTCAACCATT } \\
\text { R: TTCCCAACACACTTACCCC }\end{array}$ & Clarke and Tobutt 2003 \\
\hline EMPA002 & {$[\mathrm{AG}]_{13}$} & $\begin{array}{l}\text { F: TGACAGGTCATCATACCATTTG } \\
\text { R: CAGGATTAAGCATTGCAAATTA }\end{array}$ & Clarke and Tobutt 2003 \\
\hline EMPA003 & {$[\mathrm{AC}]_{8}$} & $\begin{array}{l}\text { F: AGCCATTCTGAAAAGGTGGA } \\
\text { R: GCATTCAGCCAACAAAATCA }\end{array}$ & Clarke and Tobutt 2003 \\
\hline EMPA004 & {$[\mathrm{GA}]_{4 A A}[\mathrm{GA}] 4 \mathrm{AA}[\mathrm{GA}]_{15}$} & $\begin{array}{l}\text { F: TACGGTAGGCTTCTGCAAGG } \\
\text { R: TTGGCAGGTTCTGTTCACAT }\end{array}$ & Clarke and Tobutt 2003 \\
\hline EMPA011 & {$[\mathrm{AG}]_{16}$} & $\begin{array}{l}\text { F: TGTGCTCACTCTCTGCTGCT } \\
\text { R: TGTGTGGGTTCACAGTCTCC }\end{array}$ & Clarke and Tobutt 2003 \\
\hline EMPA029 & {$[\mathrm{CT}]_{17}$} & $\begin{array}{l}\text { F: GCTGCTGATTGTCTGTGGTC } \\
\text { R: CAAACCCCTCTTTCTTCCAC }\end{array}$ & Clarke et. al. 2008 \\
\hline
\end{tabular}

Table 3: Allele sizes (bp) for 15 analysed samples on six loci: EMPA001, EMPA002, EMPA003, EMPA004, EMPA011 and EMPA029.

\begin{tabular}{|c|c|c|c|c|c|c|c|c|c|c|c|c|}
\hline Sample & $\begin{array}{l}\text { EMP } \\
\text { (bp) }\end{array}$ & & $\begin{array}{l}\text { EMl } \\
\text { (bp) }\end{array}$ & & $\begin{array}{l}\text { EMH } \\
\text { (bp) }\end{array}$ & & $\begin{array}{l}\text { EMI } \\
\text { (bp) }\end{array}$ & & $\begin{array}{l}\text { EMF } \\
\text { (bp) }\end{array}$ & & $\begin{array}{l}\text { EMI } \\
\text { (bp) }\end{array}$ & \\
\hline 1 & 110 & I & 165 & 181 & 169 & 177 & 162 & 164 & 195 & I & 130 & 151 \\
\hline 2 & 110 & I & 157 & I & 169 & 177 & 162 & 164 & 175 & 195 & 130 & 135 \\
\hline 3 & 110 & 118 & 155 & 171 & 165 & 173 & 162 & 164 & 185 & I & 138 & / \\
\hline 4 & 110 & / & 157 & I & 169 & 177 & 162 & 164 & 195 & I & 134 & 141 \\
\hline 5 & 110 & 118 & 155 & 163 & 165 & 173 & 162 & I & 199 & 201 & 136 & 143 \\
\hline 6 & 110 & 118 & 151 & 165 & 165 & 173 & 162 & I & 185 & I & 136 & I \\
\hline 7 & 110 & 118 & 151 & 167 & 165 & 173 & 162 & I & 181 & 201 & 142 & I \\
\hline 8 & 110 & 118 & 155 & 163 & 165 & 173 & 162 & 164 & 175 & 185 & 130 & I \\
\hline 9 & 106 & 118 & 159 & I & 169 & 177 & 164 & 164 & 195 & I & 136 & 153 \\
\hline 10 & 110 & 118 & 151 & 157 & 165 & 173 & 162 & I & 175 & 189 & 124 & 133 \\
\hline 11 & 110 & 118 & 153 & 167 & 165 & 173 & 162 & I & 185 & I & 136 & 143 \\
\hline 12 & 110 & 118 & 151 & 155 & 165 & 173 & 162 & / & 175 & 185 & 134 & 141 \\
\hline 13 & 110 & 118 & 165 & 171 & 165 & 173 & 162 & I & 185 & 201 & 130 & 149 \\
\hline 14 & 110 & 118 & 153 & 159 & 165 & 173 & 162 & 1 & 189 & 201 & 136 & 143 \\
\hline 15 & 110 & 118 & 147 & I & 169 & 173 & 162 & I & 175 & 195 & 130 & 145 \\
\hline
\end{tabular}

Table 4: Parameters of genetic variability calculated for different microsatellite loci for 14 plum genotypes: number of alleles $(\mathrm{n})$, observed $\left(\mathrm{H}_{0}\right)$, and expected $\left(\mathrm{H}_{\mathrm{e}}\right)$ heterozygosity, and probability of identity $(\mathrm{PI})$.

\begin{tabular}{|l|l|l|l|l|}
\hline Locus & $\mathrm{n}$ & $\mathrm{H}_{0}$ & $\mathrm{H}_{\mathrm{e}}$ & $\mathrm{PI}$ \\
\hline EMPA001 & 8 & 0.748971 & 1 & 0.132822 \\
\hline EMPA002 & 9 & 0.760355 & 0.909091 & 0.129158 \\
\hline EMPA003 & 4 & 0.628889 & 1 & 0.353435 \\
\hline EMPA004 & 7 & 0.798186 & 1 & 0.128038 \\
\hline EMPA011 & 10 & 0.857639 & 1 & 0.066979 \\
\hline EMPA029 & 8 & 0.842975 & 1 & 0.077522 \\
\hline Average & 7.666667 & 0.772836 & 0.984849 & $4.77394 \mathrm{E}-06$ \\
\hline
\end{tabular}


Table 5: Allele sizes (bp) and allele frequencies (in paranthesis) of $\mathbf{1 5}$ plum genotypes at six microsatellite loci.

\begin{tabular}{|c|c|c|c|c|c|c|}
\hline Allele/locus & EMPA001 & EMPA002 & EMPA003 & EMPA004 & EMPA011 & EMPA029 \\
\hline A & $\begin{array}{c}118 \\
(0.444) \\
\end{array}$ & $\begin{array}{c}155 \\
(0.038) \\
\end{array}$ & $\begin{array}{c}162 \\
(0.467) \\
\end{array}$ & $\begin{array}{c}164 \\
(0.286) \\
\end{array}$ & $\begin{array}{c}124 \\
(0.042) \\
\end{array}$ & $\begin{array}{c}133 \\
(0.091) \\
\end{array}$ \\
\hline B & $\begin{array}{c}147 \\
(0.037)\end{array}$ & $\begin{array}{c}157 \\
(0.038)\end{array}$ & $\begin{array}{c}164 \\
(0.033)\end{array}$ & $\begin{array}{c}175 \\
(0.238)\end{array}$ & $\begin{array}{c}130 \\
(0.208)\end{array}$ & $\begin{array}{c}135 \\
(0.091)\end{array}$ \\
\hline $\mathrm{C}$ & $\begin{array}{c}151 \\
(0.148)\end{array}$ & $\begin{array}{c}159 \\
(0.038)\end{array}$ & $\begin{array}{c}173 \\
(0.367)\end{array}$ & $\begin{array}{c}181 \\
(0.048)\end{array}$ & $\begin{array}{c}134 \\
(0.083)\end{array}$ & $\begin{array}{c}141 \\
(0.182)\end{array}$ \\
\hline $\mathrm{D}$ & $\begin{array}{c}153 \\
(0.074)\end{array}$ & $\begin{array}{c}163 \\
(0.077)\end{array}$ & $\begin{array}{c}177 \\
(0.133)\end{array}$ & $\begin{array}{c}185 \\
(0.190)\end{array}$ & $\begin{array}{c}136 \\
(0.208)\end{array}$ & $\begin{array}{c}143 \\
(0.273)\end{array}$ \\
\hline E & $\begin{array}{c}155 \\
(0.111) \\
\end{array}$ & $\begin{array}{c}165 \\
(0.423) \\
\end{array}$ & I & $\begin{array}{c}189 \\
(0.048)\end{array}$ & $\begin{array}{c}138 \\
(0.042) \\
\end{array}$ & $\begin{array}{c}145 \\
(0.091) \\
\end{array}$ \\
\hline $\mathrm{F}$ & $\begin{array}{c}157 \\
(0.074) \\
\end{array}$ & $\begin{array}{c}167 \\
(0.077) \\
\end{array}$ & I & $\begin{array}{c}195 \\
(0.143) \\
\end{array}$ & $\begin{array}{c}142 \\
(0.042) \\
\end{array}$ & $\begin{array}{c}149 \\
(0.091) \\
\end{array}$ \\
\hline G & $\begin{array}{c}159 \\
(0.037)\end{array}$ & $\begin{array}{c}169 \\
(0.192) \\
\end{array}$ & I & $\begin{array}{c}199 \\
(0.048)\end{array}$ & $\begin{array}{c}185 \\
(0.083) \\
\end{array}$ & $\begin{array}{c}151 \\
(0.091)\end{array}$ \\
\hline $\mathrm{H}$ & $\begin{array}{c}165 \\
(0.074)\end{array}$ & $\begin{array}{c}171 \\
(0.077)\end{array}$ & I & I & $\begin{array}{c}189 \\
(0.042)\end{array}$ & $\begin{array}{c}153 \\
(0.091)\end{array}$ \\
\hline I & I & $\begin{array}{c}181 \\
(0.038) \\
\end{array}$ & I & I & $\begin{array}{c}195 \\
(0.083) \\
\end{array}$ & I \\
\hline$J$ & I & I & I & I & $\begin{array}{c}201 \\
(0.167) \\
\end{array}$ & I \\
\hline $\begin{array}{c}\text { Allele } \\
\text { number }\end{array}$ & 8 & 9 & 4 & 7 & 10 & 8 \\
\hline
\end{tabular}

\section{ACKNOWLEDGMENTS}

I would like to express my gratitude to Janja Kotnik and Anja Ivanuš for assistance with the experiments.

\section{REFERENCES}

1. Cervera MT, Cabezas JA, Sancha JC, Martinez de Toda F, Martinez-Zapater JM. Application of AFLPs to the characterisation of grapevine Vitis vinifera L. genetic resources. A case study with accessions from Rioja (Spain). Theor. Appl. Genet. 1998; 97:51-59.

2. Clarke JB, Sargent DJ, Bošković RI, Belaj A, Tobutt KR. A cherry map from the interspecific cross Prunus avium "Napoleon" $\times$ P. nipponica based on microsatellite, genespecific and isoenzyme markers. Tree Genet. Genomes. 2009;5:41-51.

3. Clarke JB, Tobutt KR. Development and characterisation of polymorphic microsatellites from Prunus avium "Napoleon" Mol. Ecol. Notes. 2003;578-580.

4. Decroocq V, Hagen LS, Fave MG, Eyquard JP, Pierronnet A. Microsatellite markers in the hexaploid Prunus domestica species and parentage lineage of three European plum cultivars using nuclear and chloroplast simple-sequence repeats. Mol. Breeding. 2004;13:135-142.

5. Dice LR. Measures of the amount of ecologic association between species. Ecology. 1945;297-302.

6. Donoso JM, Aros D, Meneses C, Narvaez C, Infante R. Genetic relationships in apricot (Prunus armeniaca L.) using SSR markers and their implications for breeding. J. Food Agric. Environ. 2008;6(3\&4):378-382.
7. Doyle JJ, Doyle JL. A rapid DNA isolation procedure for small quantities of fresh leaf tissue. Phytochem. Bull. 1987;19(1):11-15.

8. Gross BL, Volk GM, Richards CM, Forsline PL, Fazio G, Chao CT. Identification of "duplicate" accessions within the USDA-ARS National Plant Germplasm System Malus collection. J. Amer. Soc. Hort. Sci. 2012;137(5):333-342.

9. Guarino C, Santoro S, Simone LD, Cipriani G. Prunus avium: nuclear DNA study in wild population and sweet cherry cultivars. Genome. 2009;52:320-337.

10. Koehmstedt A, Aradhya M, Soleri D, Smith J, Polito V. Molecular characterization of genetic diversity, structure, and differentiation in the olive (Olea europea L.) germplasm collection of the United States Department of Agriculture. Genet. Resources Crop Evol. 2011;58:519-531.

11. Laucou V, Lacombe T, Dechesne F, Siret R, Bruno JP, Dessup M, Dessup T, Ortigosa P, Parra P, Roux C, Santoni S, Vares D, Peros JP, Boursiquot JM, This P. High throughput analysis of grape genetic diversity as a tool for germplasm collection management. Theor. Appl. Genet. 2011;122:1233-1245.

12. Lund B., Ortiz R., Skovgaard IM, Waugh R., Andersen SB. Analysis of potential duplicates in barley gene bank collections using re-sampling of microsatellite data. Theor. Appl. Genet. 2003;106:1129-1138.

13. Meglič V, ŠuštarVozlič J, Luthar Z, Ferant N, Čerenak A, Šško M, Cvelbar J. Slovene plant gene bank and genetic resources programme. In: Meglič V. (ed.). Seednet the way ahead: book of abstracts. Ljubljana, Kmetijski inštitut Slovenije, p. 14, 2014.

14. Perrier X, Jacquemoud-Collet JP. DARwin-5.0. Dissimilarity analysis and representation for Windows. CIRAD, Montpellier, 2005. 
15. Saitou N, Nei M. The Neighbor-joining method: A new method for reconstructing phylogenetic trees. Mol.Biol. Evol. 1989; 4:406-425.

16. Struss S, Ahmad R, Southwick SM, Boritzki M. Analysis of sweet cherry (Prunus avium L.) cultivars using SSR and AFLP markers. J. Amer. Soc. Hort. Sci. 2003;128(6)904909.

17. Tessier C, David J, This P, Boursiquot JM, Charrier A. Optimisation of the choice of molecular markers for varietal identification in Vitis vinifera L. Theor. Appl. Genet. 1999;98:171-177.

18. Wagner HW, Sefc KM. IDENTITY 1.0 Centre for Applied Genetics, University of Agricultural Sciences Vienna, 1999.

19. Zulini L, Russo M, Peterlunger E. Genotyping wine and table grape cultivars from Apulia (Southern Italy) using microsatellite markers. Vitis. 2002;41:183-187. 


\section{Identifikacija morebitnih duplikatov med akcesijami sliv (Prunus domestica L.) znotraj Slovenske rastlinske genske banke z uporabo molekulskih markerjev}

\section{IZVLEČEK}

Slovenska rastlinska genska banka skrbi za ohranjanje, vzdrževanje in vrednotenje tradicionalnih kultivarjev in drugih uporabnih genotipov rastlin. Fakulteta za kmetijstvo in biosistemske vede skrbi med drugim tudi za številne akcesije sliv (Prunus domestica L.). Med 15 izbranimi akcesijami, smo s pomočjo šestih mikrosatelitskih lokusov želeli poiskati morebitne duplikate. Z mikrosatelitskimi markerji smo v povprečju namnožili 7.67 alelov na lokus in dobili od 4 do 10 različnih alelov na posamezen lokus. Za računanje genetskih oddaljenosti med proučevanimi akcesijami smo izračunali Dice koeficient in izrisali dendrogram. Šest mikrosatelitskih lokusov je zadostovalo za razlikovanje med akcesijami. Med preučevanimi akcesijami nismo našli duplikatov.

Ključne besede: genska banka, podvojene akcesije, Prunus domestica, slive, mikrosatelitski markerji 